\title{
A música de braço com a moda: mulheres compositoras na imprensa feminina (Rio de Janeiro, 1852-1902)
}

Music arm-in-arm with fashion: women composers in feminine press (Rio de Janeiro, 1852-1902) 


\section{Avelino Romero Pereira ${ }^{1}$}

ORCID: https://orcid.org/0000-0001-7712-5862

[resumo] 0 artigo apresenta um levantamento dos contatos entre música e moda na imprensa feminina do Rio de Janeiro oitocentista, tomando-se o teatro e os salões como espaços privilegiados em que a música era o elemento mediador das relações de sociabilidade das elites e das camadas médias de então. Foca-se o protagonismo feminino pela identificação de mulheres que compuseram e publicaram partituras nos suplementos musicais das revistas. As "danças da moda" frequentam essas páginas, em cujas edições os suplementos musicais alternam-se com a ilustração de figurinos: a música de braço com a moda, ambas compartilhadas com as leitoras como objetos a serem consumidos e reproduzidos. A análise enfatiza escritos sobre música publicados n'O Jornal das Senhoras (1852-1855) e os concursos para compositoras realizados pel'A Estação em 1902, entre outras situações e fontes.

\section{[palavras-chave] Música e moda. Mulheres compositoras. Imprensa feminina.} Rio de Janeiro oitocentista.

[abstract] This article presents the approximations between music and fashion as seen in nineteenth-century feminine press in Rio de Janeiro. Theatre and ballrooms are approached as privileged spaces where music mediated the sociability of the elites and middle classes. The paper focuses on female protagonism by identifying women who composed and published sheet music in magazine supplements. The "fashion dances" frequently appeared in those pages, alternated with costume illustrations, and music and fashion were both shared by the female readers as objects to be consumed and reproduced. This present analysis emphasizes, among other things, texts about music published in Jornal das Senhoras (1852-55), as well as the contests for women composers held by A Estação in 1902.

[keywords] Music and fashion. Women composers. Feminine press. Nineteenth-century Rio de Janeiro.

Recebido em: 29-01-2019

Aprovado em: 09-06-2019

\footnotetext{
${ }^{1}$ Historiador e pianista. Doutor em História pela UFF. Mestre em História pela UFRJ. Professor de His-
} tória da Música no Instituto Villa-Lobos da Universidade Federal do Estado do Rio de Janeiro (Unirio). 


\title{
A música no espelho da moda
}

\begin{abstract}
Do hotel podíamos, eu e minha leitora, sempre de braço, ir até o teatro lírico. É ali onde mais vezes se apresenta o nosso mundo elegante, sempre cheio de seduções, sempre ébrio de encantos e de delícias. $O$ teatro lírico é o teatro por excelência aristocrático: o madamismo vaidoso é dos seus camarotes que ostenta as suas sedas, as suas galas, assoberbado com os admiradores que cativa, e deixa prostrados ao peso de tanta graça. Muitos vão lá sem saberem, sem se importarem mesmo com a ordem dos espetáculos: é que os admiradores da arte naquele teatro são mui poucos [...]. Havemos de ir ao lírico, amável leitora, para admirarmos os belos toilettes, as sedas de gosto, as cassas, os bareges lindíssimos, com que ali se apresenta o nosso madamismo ${ }^{2}$.
\end{abstract}

O Espelho é um desses exemplos clássicos da imprensa feminina do Rio de Janeiro oitocentista. Essa "revista semanal de literatura, modas, indústria e artes", que circulou brevemente, entre setembro de 1859 e janeiro de 1860, traz no nome uma indicação do público a que se dirige ${ }^{3}$ : remete ao objeto útil a de quem avalia o vestir-se e o adornar-se, associado à vaidade, atribuída ao feminino. Mas a capacidade de o próprio objeto criar imagens virtuais logo direciona o olhar para o mundo de aparências, no qual se dá a performance social. 0 espelho é a metonímia que nomeia a coisa no lugar do ato ou da pessoa que o pratica, mas é igualmente a metáfora que desliza para o jogo em que a música é chamada a dar o braço à moda, uma refletindo a outra. A moda incide nos ambientes nos quais a música está, ao mesmo tempo que a música é entreouvida onde aparentemente não deveria estar: a Crônica elegante de uma revista feminina, como a que me serve de epígrafe, deveria tratar apenas da moda, mas logo instaura-se um fluxo de sentidos e representações que avança sobre os espaços sociais e os comportamentos. Observando que a elegância pode ocultar os defeitos, pois ela "é a ficção prostrando-nos em um doce enlevo" ${ }^{4}$ o redator convida a leitora para um passeio e é o próprio texto que passeia entre a literatura e a publicidade, percorrendo endereços das ruas do Ouvidor e dos Ourives, para repousar no teatro lírico. Ali, o teatro dos sentidos encena as aproximações entre a música e a moda, o olhar impõe-se ao ouvir, e mais se observa do que se escuta. 0 redator, já invocando a cumplicidade da leitora, sugere que juntos possam não só admirar "o que de bom houver", mas também rir

\footnotetext{
2 Crônica elegante. O Espelho. Rio de Janeiro, n. 4, p. 11-12, 25 set. 1859.

${ }^{3}$ Esse traço de vários dos periódicos do século XIX é apontado por Buitoni (1986, p. 7), Muzart (2003, p. 228); e Luca (2018, p. 448). Tanto para Dulcília Buitoni quanto para Tania de Luca, o que define a imprensa feminina é o público-alvo, podendo essas publicações terem sido produzidas por mulheres ou não. Esse entendimento, que adoto aqui, é também o de Duarte (2016, p. 15).

${ }^{4}$ Crônica elegante. O Espelho. Rio de Janeiro, n. 4, p. 11-12, 25 set. 1859.
} 
das "figurinhas caricatas", aquelas que "costumam repimpar-se naqueles camarotes, ouvindo o que não entendem, fazendo o mesmo que muita gente boa, que aplaude porque vê os outros aplaudirem, e que desaprova por imitação" ${ }^{\text {. }}$.

Em seu número de estreia, o periódico explica o próprio nome, tomando a imprensa como um espelho das ideias e do pensamento ${ }^{6}$. Como metáfora, o espelho é pródigo e as imagens se multiplicam. 0 espelho capta-as dos ambientes sociais e as reproduz nas páginas da revista. Ao mesmo tempo, é o modelo, em que a leitora deveria mirar-se. Daí a intenção pedagógica do cronista ao referir os endereços das casas comerciais nas quais a leitora encontraria orientação segura para cuidar da aparência e cultivar a elegância ao mesmo tempo que a exorta a se comportar socialmente em um ambiente complexo como o da ópera. Ao sugerir que a leitora se some a ele na censura dos comportamentos ridicularizados, o redator na verdade acende o alerta para quem podia se ver refletida, não no padrão esperado e correto, mas naquele que é alvo de escárnio.

A crônica coloca-nos de frente para o tema que move este trabalho, ainda em caráter exploratório, e que objetiva identificar personagens e situações em torno das quais a música é inserida na imprensa feminina do Oitocentos, em conexão com os conceitos, valores e atitudes associados à moda. A música integra o sistema da moda valendo-se como um pretexto que atrai os olhares para os teatros e salões. Mas, se as crônicas refletem o que lá se passa, o jogo de espelhos termina por atrair a própria música para a imprensa feminina. E não só como parte dos relatos. Ela comparece também na forma de suplementos musicais, partituras anunciadas como "da moda". Aliás, como diz Dulcília Buitoni, "a pedra de toque da imprensa feminina é a novidade" (BUITONI, 1986, p. 13), e assim é apresentada a música impressa distribuída pelos periódicos. "Em vez da notícia, a novidade”, diz a autora. Ela acrescenta: "Muitas vezes nascidos por causa da moda em vestuário, os veículos femininos impregnaram-se da febre do novo, que é fundamental no sistema da moda e que passou a contaminar todos os outros conteúdos publicados a seu lado" (BUITONI, 1986, p. 14).

Será uma constante: em junho de 1839, o Correio das Modas fala em "contradanças dedicadas à moda"; em março de 1854, uma das redatoras d'O Jornal das Senhoras anuncia uma "valsa da moda"; em janeiro de 1863, o editorial da primeira edição do Jornal das Famílias, inclui entre seus conteúdos "figurinos de moda, peças de música inéditas"; e, em 1902, A Estação lança um concurso "exclusivamente reservado às compositoras e amadoras nacionais" para uma composição "original" a ser publicada na "seção musical".

Como veremos ao longo deste artigo, mulheres compositoras não eram novidade e a imprensa feminina buscava dar-lhes visibilidade. A Estação já publicara partituras de compositoras, como a valsa Esmeralda, "gentilmente oferecida pela distinta amadora" Mariazinha Lazary Guerreiro, em 19007. Um dos papeis das revistas femininas foi estimular a expressão pública das mulheres, e essa colaboração espontânea confirma isto. Na sequência, ao realizar o concurso, a revista amplia esse espaço:

\footnotetext{
Crônica elegante. O Espelho. Rio de Janeiro, n. 4, p. 11-12, 25 set. 1859.

${ }^{6} 0$ espelho. 0 Espelho. Rio de Janeiro, n. 1, p. 8, 4 set. 1859.

Seção musical d’A Estação. A Estação (suplemento literário), Rio de Janeiro, ano 29, n. 16, p. 94, 31 ago. 1900.
} 
Entre nós são muitas as senhoras que já conseguiram um belo nome, nas letras, nas artes e mesmo nas ciências.

Honrando a atividade feminil que tão pujante se mostra por toda a parte, lembrou-se $A$ Estação de abrir um concurso musical para uma valsa, concurso que será disputado exclusivamente por nossas compositoras que as temos e da mais fina estirpe ${ }^{8}$.

Um mês depois de anunciado, a redação informa o adiamento do concurso, observando que a ideia "não podia deixar de despertar sério entusiasmo", mas que as interessadas ponderaram que o prazo era curto ${ }^{9}$. 0 concurso não se realizou e, na data em que seria publicada a vencedora, dizia-se que "deve ser muito grato aos nossos muitíssimos leitores e assinantes saber que é de uma senhora a belíssima valsa Ciciar da Brisa que hoje lhe oferece A Estação, como mimo, em cumprimento do seu programa"10. 0 texto sugere o inusitado da publicação, visto que eram comuns na revista as partituras compostas por homens, e a novidade foi saudada como "mais uma prova ardente de talento inato de brasileira"11. A compositora é Marietta Leite de Castro, então com 17 anos, "filha de um zeloso funcionário público aposentado"12 e recém-admitida no curso de piano do Instituto Nacional de Música. $A$ Estação registra que, apesar de jovem, "não é esta a sua primeira composição musical, outras muitas possui a gentil senhorita, cujo nome hoje honra a nossa página"13.

A revista deve ter tido dificuldade para mobilizar compositoras, pois, "não recuando ante nenhum sacrifício", lança novo concurso sob o chamativo título "Grande e importante concurso musical"14. Agora seria uma schottisch, que deveria ser original e "de meia dificuldade, para que assim esteja bem ao alcance das amadoras"15. A vencedora seria uma ex-aluna de Chiquinha Gonzaga, Leontina Torres ${ }^{16}$. A schottisch Marthe, com o retrato da autora, seria distribuída no suplemento. Segundo a edição de 15 de outubro de 1902, o concurso "se transformou em verdadeiro triunfo" para Leontina Torres, cuja composição "teve uma saída extraordinária", e a revista resolve oferecer também a partitura de Saudosa, a segunda colocada, composta por

\footnotetext{
${ }^{8}$ Concurso musical. A Estação (suplemento literário), Rio de Janeiro, ano 31, n. 3, p. 13, 15 fev. 1902.

${ }^{9}$ Concurso. A Estação (suplemento literário), Rio de Janeiro, ano 31, n. 5, p. 25, 15 mar. 1902.

10 Seção musical. A Estação (suplemento literário), Rio de Janeiro, ano 31, n. 11, p. 61,15 jun. 1902. A partitura encontra-se na Divisão de Música e Arquivo Sonoro da Fundação Biblioteca Nacional.

${ }^{11}$ Seção musical. A Estação (suplemento literário), Rio de Janeiro, ano 31, n. 11, p. 61, 15 jun. 1902.

12 Seção musical. A Estação (suplemento literário), Rio de Janeiro, ano 31, n. 11, p. 61, 15 jun. 1902.

13 Seção musical. A Estação (suplemento literário), Rio de Janeiro, ano 31, n. 11, p. 61, 15 jun. 1902.

${ }^{14}$ Grande e importante concurso musical. A Estação (suplemento literário), Rio de Janeiro, ano 31, n. 14, p. 79, 31 jul. 1902.

${ }^{15}$ Grande e importante concurso musical. A Estação (suplemento literário), Rio de Janeiro, ano 31, n. 14, p. 79, 31 jul. 1902.

${ }^{16}$ A Fundação Biblioteca Nacional conserva um exemplar da habanera Leontina, de Chiquinha Gonzaga, que traz a dedicatória: "À minha distinta discípula Leontina Gentil Torres". Os suplementos relativos ao concurso também estão na Divisão de Música e Arquivo Sonoro da Fundação Biblioteca Nacional.
} 
uma assinante, Rita Tamborim Peixoto Guimarães ${ }^{17}$. Para completar o sucesso, abriu-se novo concurso, que premiaria as valsas Syrius, de Marietta, e Juracy, de Leontina, saudada como a "autora da célebre schottisch Marthe"18. A revista ditava a moda e celebrizava a música.

Impossível não comentar o suplemento que traz a partitura da valsa Syrius, de Marietta Leite de Castro, cuja capa traz uma ilustração bastante indicativa dessas aproximações entre a moda e a música. Sobre um motivo floral que se estende por toda a margem esquerda, uma jovem representada no alto da página segura uma cornucópia de onde despeja um emaranhado de objetos, adereços femininos: braceletes, pulseiras, alfinetes, broches, uma fivela, um pente, entre outros. No pé da página, veem-se instrumentos musicais - uma lira, um bandolim, uma flauta e um violino - e, ao lado destes, são reproduzidas a capa da própria revista e um trecho de música. Sob o título da composição, do nome da autora e das informações relativas ao concurso realizado, avisa-se que "com este frontispício acrescentamos à seção musical e à seção de modas outra de objetos de fantasia para senhoras"19. Embora a ornamentação não fosse regra, motivos florais eram frequentes nas capas de partituras editadas no Rio de Janeiro na passagem do século XIX para o XX, mas a profusão de elementos que pode ser vista nesse caso constitui uma exceção, explicável pela intenção de representar visualmente a nova seção incorporada à revista. Por outro lado, é uma representação que reforça a inserção da música no sistema da moda.

Partindo de um levantamento desses contatos entre música e moda, a pesquisa busca o protagonismo feminino na imprensa e nos ambientes percorridos pelos redatores, com destaque para as mulheres compositoras e para a identificação de senhoras e senhoritas nascidas no Brasil ou estrangeiras residentes que compuseram e publicaram partituras nos suplementos musicais da imprensa feminina, a qual reforçava assim o apelo às leitoras. No espelho da imprensa, esses suplementos reproduzem quase ao infinito o que se ouve nos salões e teatros. Distribuído entre as leitoras, e uma vez sobre um piano e em hábeis mãos, cada exemplar volta a ser reproduzido na forma sonora que poria em movimento outros corpos. São as danças da moda, curiosa e apropriadamente nomeadas no feminino: a valsa, a quadrilha, a schottisch, a polca e também a mazurca e a redowa. Todas de origem europeia. As habaneras, afrocubanas, pareciam excluídas daquele mundo elegante pelo qual circulavam essas revistas...

\section{De braços pelos salões}

Prosseguindo a identificação das representações da música em conexão com a moda, destaco três situações que me parecem paradigmáticas da forma como a música é comumente inserida nas revistas femininas: a crônica de um evento extraordinário extraída d'A Estação, a

\footnotetext{
17 Segundo concurso musical. A Estação (suplemento literário), Rio de Janeiro, ano 31, n. 19, p. 107, 15 out. 1902 .

18 Sumário. A Estação (suplemento literário), Rio de Janeiro, ano 31, n. 23, p. 131, 15 dez. 1902. Leontina era mesmo uma campeã: no ano seguinte foi novamente premiada com a valsa Brasileira, dessa vez em terceiro lugar e concorrendo com homens no concurso promovido pela semanário humorístico Tagarela (Rio de Janeiro, ano 2, n. 75, 30 jul. 1903).

19 CASTRO, Marietta Leite de. Syrius: valsa. Partitura para piano. 4 p. Suplemento de A Estação, Rio de Janeiro, ano 31, n. 23, 15 dez. 1902.
} 
crônica musical regular do Jornal das Senhoras e a coluna de moda do Correio das Modas. São três tipos diferentes de textos, correspondendo a distintos modos de representar essas interfaces. E chamo a atenção para o terceiro caso que, embora trate "especificamente" da moda, a música ali comparece como um elemento indissociável dos interesses femininos presentes nas revistas.

A Estação, "jornal ilustrado para a família”, impresso em Paris e editado pela Livraria Lombaerts \& Cia. no Rio de Janeiro entre 1879 e 1904, era a continuação da edição brasileira de La Saison, que circulara no país entre 1872 e 1878. Quinzenal, trazia uma parte de modas, que replicava textos e modelos parisienses, uma parte literária, contendo poesia, contos, noticiário, bibliografia, crônica teatral, e a elas podiam somar-se, na "seção musical", partituras, como as mencionadas. 0 evento em destaque é descrito em uma edição de julho de 1882: um sarau no Palácio Isabel, oferecido por suas altezas “à nossa melhor sociedade”, como diz o redator ${ }^{20}$. Após mencionar "a elegância nos adornos das damas" e "a extrema amabilidade e ameno trato dos augustos príncipes", passa ao programa da parte musical em que a princesa Isabel apresenta-se como pianista e cantora ao lado de outros musicistas. Findo o concerto, seguem-se as danças e a "Sereníssima Princesa" é novamente o destaque, dançando com membros do corpo diplomático e do gabinete de ministros. 0 redator descreve então as toilettes, começando pelo moiré azul-claro da imperatriz e pelo vestido da princesa, "curto e de cetim cor de rosa desmaiada, guarnecido por folhos plissés de filós de seda" e acrescido de uma basquine de cetim. Observa ainda que "fino ramo de flores da cor da toilette ornava-lhe o peito", e que a princesa "não trazia jóias". Em seguida, descreve as toilettes de algumas damas entre as cerca de 300 pessoas presentes. Tendo a princesa como modelo, são os padrões de sociabilidade da elite imperial e os sinais de distinção feminina que estão aí captados: a hospitalidade, as habilidades como pianista e cantora, a dança com os convidados, as vestimentas, os adornos.

Além da dimensão estética, que talvez contasse menos do que o desempenho social, que função se podia esperar do domínio do piano ou da voz por uma mulher da sociedade? Quem responde é Alina, que, em março de 1854, inaugura o "Boletim Musical” do Jornal das Senhoras, periódico editado no Rio de Janeiro entre 1852 e 1855.0 motivo é solene, as homenagens fúnebres à rainha D. Maria II, de Portugal, e a cronista introduz um comentário à música ouvida na igreja de São Francisco de Paula. Em outro artigo da mesma edição, Alina já tinha descrito a ornamentação da igreja e se refere agora à música, dizendo que seria criticada se não lhe desse algumas linhas:

Sendo este jornal o órgão dos progressos e da civilização do sexo feminino, e sendo a música uma das prendas mais apreciadas, e que mais concorre para interessar o mundo elegante em perenes adorações pelas senhoras que o atraem pela suavidade da voz, pelo gosto e belezas da expressão, ou finalmente pelo brilhantismo da execução instrumental ${ }^{21}$.

\footnotetext{
20 Palácio Isabel. A Estação, Rio de Janeiro, ano 11, n. 14, p. 156 e 158, 31 jul. 1882.

${ }^{21}$ Boletim Musical. Jornal das Senhoras, Rio de Janeiro, ano 3, n. 11, p. 87-88, 12 mar. 1854.
} 
Novamente, o canto e o piano associados ao feminino, como um atributo que lhe é próprio e um modo de se apresentar socialmente. A música é uma prenda, e das mais apreciadas, na sedução junto ao "mundo elegante". Assim como o vestuário e os ornamentos, a música compõe a identidade feminina e o pertencimento ao grupo social ${ }^{22}$. E como já mencionado, a imprensa feminina cumpre o papel pedagógico, fornecendo insumos para a fixação dos padrões de sociabilidade e a construção da identidade. 0 comentário sobre a música justifica-se por ser oJornal das Senhoras "o órgão dos progressos e da civilização do sexo feminino", como proclama a redatora, em consonância com a linha editorial do periódico, desde sua fundação em 1852, por iniciativa de Joana Paula Manso de Noronha ${ }^{23}$.

A terceira situação é extraída de uma edição de abril de 1839 do Correio das Modas, “jornal crítico e literário das modas, bailes, teatros, etc."24, publicado no Rio de Janeiro pelos irmãos Laemmert entre 1839 e 1840.0 redator de "Modas" descreve uma cena de baile: "A música terminava seus últimos acentos; o som das derradeiras suavíssimas notas de uma quadrilha elegante, harmoniosa, ia morrendo, e ainda eu ouvia toda a quadrilha, ainda me parecia dançar", sendo ele então interrompido em seu idílio por "uma jovem fluminense" com quem dançara, pretexto para observar que ela "trajava primorosamente e com excelente gosto" e para descrever em detalhes seu vestido e adornos ${ }^{25}$. Na sequência, diz que tudo não passava de um devaneio despertado pela leitura do Correio: o figurino descrito era o que vinha em suplemento naquela edição, e a quadrilha de contradanças seria oferecida em breve, atribuindo-se o atraso ao litógrafo. A imagem representava a jovem trajando conforme a descrição, e tendo ao fundo um piano do qual só vemos a estante com um volume. Pelo visto, o litógrafo tardaria ainda mais, pois a prometida quadrilha só sairia em junho. Na ocasião, a distribuição da partitura pelo periódico é tratada como novidade a requerer justificativa da redação. Isto, somado às dificuldades técnicas para aprontar o suplemento, sugere ser a primeira vez em que ocorria no país:

Música!! - dirão alguns perluxos - é impróprio. Que importa esta arguição ao Correio quando ele tem a convicção de que as suas contradanças hão de agradar ao público a quem tanto deseja ser aprazível. - Música!! Qual será a pessoa que dela não gostará? Qual será a Dama que não folgará de abrir no seu piano o Correio com a descrição de seu vestido de baile e de tocar as contradanças

\footnotetext{
22 Em uma coletânea sobre o piano na música europeia do século XIX, diz o musicólogo Larry Todd que "mulheres de elevada condição social eram encorajadas a mostrar, ou esperava-se que mostrassem algum nível de habilidade artística como intérpretes ao teclado” (TODD, 1994, p. XI. Tradução minha para: "Women of social standing were encouraged or expected to show some measure of artistic accomplishment as performers at the keyboard".).

23 No editorial de apresentação, a fundadora dizia-se "em campanha" e com "a vontade e o desejo de propagar a ilustração, e cooperar com todas as suas forças para o melhoramento social e para a emancipação moral da mulher" (NORONHA, Joana Paula Manso de. Às nossas assinantes. 0 Jornal das Senhoras, Rio de Janeiro, ano 1, n. 1, p. 1-2, 1이an. 1852). Fundado como 0 Jornal das Senhoras, a partir da edição de número 10 de 1853, de 6 março, passou a chamar-se Jornal das Senhoras.

24 Modas. Correio das Modas, Rio de Janeiro, ano 1, v. 1, n. 17, p. 137-138, 27 abr. 1839.

25 Modas. Correio das Modas, Rio de Janeiro, ano 1, v. 1, n. 17, p. 137-138, 27 abr. 1839.
} 
dedicadas à moda? 0 sentimento que ele tem é a impressão não ter saído tão nítida como desejava, porém os assíduos cuidados e o desvelado trabalho delirão este pequeno defeito ${ }^{26}$.

Eis a função do piano representado com o volume sobre a estante na gravura do figurino impressa na outra edição. Assim como a música e a moda andam de braços pelos salões, também os suplementos, o de moda e o musical, juntam-se sobre o piano da leitora. Nada mais natural ainda que o redator tenha que justificar -, pois, afinal, eram as situações sociais mediadas pela música as grandes oportunidades para as senhoras luzirem seus trajes, ornamentos e penteados.

\section{Sobre os pianos, a música da moda}

A presença de uma partitura em uma revista feminina era novidade a ser anunciada. Embora o Jornal das Senhoras já as viesse publicando há dois anos, uma de suas redatoras de moda, Ritinha, escrevendo em março de 1854, sentiu necessidade de justificar "a frescura com que, devendo falar em modas", estava "tratando da música e seus efeitos". ${ }^{27} 0$ motivo era uma valsa executada com sucesso em Paris e na qual, se a leitora dedicasse um "bocadinho da [...] atenção ao pouco estudo que ela requer", descobriria "uma novidade agradável"28. A alternância entre moda e música nos suplementos era anunciada semanalmente no expediente do periódico, e ela comenta:

Hoje, querida leitora, é o último domingo do mês; há restrita obrigação de se vos dar uma peça de música ou uma estampa de bordados; e como tive a prioridade de escolher uma ou outra cousa para presentear-vos, escolhi a música, pela razão de há muito não se vos ter feito igual presente; eis tudo explicado.

Mas tive de fazer o artigo de fundo para este fim, e então entendi não dever rejeitar o título dos meus artigos somente por ter de dizer duas palavras em favor da música que vos ofereço. 0 meu mestre de piano, mestre que passou por primeiro na nossa terra, e já foi mestre de muitas moças d'outro tempo, dizia, e ainda diz com toda a autoridade de mestre velho - que a música deve executar-se enquanto for da moda, depois - estante com ela - porque já está velha. Ora, se o mestre diz que a Norma não se deve cantar, porque já não é moda, não é muito que eu dê, sob o título modas, uma valsa da moda às minhas queridas leitoras. ${ }^{29}$

\footnotetext{
${ }^{26}$ Música!. . Correio das Modas, Rio de Janeiro, ano 1, v. 1, n. 25, p. 204, 22 jun. 1839. Infelizmente, a partitura não se encontra na Hemeroteca Digital da Biblioteca Nacional (RJ), de cujo acervo nos valemos para este trabalho.

27 Modas. Jornal das Senhoras, Rio de Janeiro, ano 3, n. 13, p. 97-98, 26 mar. 1854.

28 Modas. Jornal das Senhoras, Rio de Janeiro, ano 3, n. 13, p. 97-98, 26 mar. 1854.

${ }_{29}$ Modas. Jornal das Senhoras, Rio de Janeiro, ano 3, n. 13, p. 97-98, 26 mar. 1854.
} 
Parte da graça do texto dessa moreninha de 16 anos, como ela se apresenta ${ }^{30}$, está na ironia de um "mestre velho" defendendo a moda. A ênfase na música "da moda" lembra um traço característico da imprensa: seu caráter efêmero. Ao envelhecer rapidamente, a música seria retirada do piano, e tamanha volatilidade explica que à sua execução bastasse um "bocadinho da atenção ao pouco estudo que ela requer". Explica também que os periódicos oferecessem novidades musicais para repor as que saíam de moda.

Um olhar mais detido sobre o já mencionado "Boletim Musical" do Jornal das Senhoras ajuda a situar a questão. Inaugurado por Alina, como vimos, era a seção dedicada a tratar dos eventos relacionados à música, destacando os espetáculos líricos encenados e a edição de partituras, muitas vezes de peças ouvidas em saraus e concertos. Justapõe-se à intenção pedagógica a difusão do circuito comercial da música, que articula, em uma ponta, os espetáculos públicos acessíveis mediante a aquisição de ingressos e, na outra, a venda de partituras para consumo doméstico. Depois de assinar o "Boletim Musical" por cinco edições seguidas, Alina cede o espaço para Joaninha, e um diferencial nos textos desta é a maior ênfase na divulgação de partituras recém-editadas e dos endereços onde as encontrar. 0 atrativo para sua aquisição era uma execução pública que ela tivesse testemunhado, assegurando credibilidade à indicação. Em maio de 1854, após recomendar as composições editadas e as que ouviu, Joaninha dirá que "em música, não se apresentou nenhuma outra novidade"31. A música assume sempre o caráter da moda, da novidade que merece ser divulgada pela revista e consumida pelas leitoras que quisessem se inserir no padrão de identidade e gosto.

Muito já se escreveu sobre o caráter pioneiro e inovador d'O Jornal das Senhoras ao defender a emancipação feminina, especialmente por ser redigido por mulheres ${ }^{32}$. Nesse sentido, nota-se nos textos de Alina um forte protagonismo diante das questões relativas à música presentes na esfera pública. Em seu terceiro artigo para o "Boletim Musical", por exemplo, a redatora é extremamente crítica à situação do teatro lírico e do Conservatório de Música:

Quando nutrimos desejos de chamar a atenção de nossas leitoras para alguma interessante ocorrência havida no mundo musical, lastimamos que a ópera lírica esteja tão pouco fértil de novidades, que nos não forneça assunto para este artigo. Se recorrermos ao conservatório de música para nos auxiliarmos de alguma cousa, também nada colheremos, pois que ignoramos se ainda existe tal instituição. Quiséramos que o Conservatório se colocasse na altura de sua verdadeira

\footnotetext{
30 Modas. Jornal das Senhoras, Rio de Janeiro, ano 3, n. 3, p. 17-18, 15 jan. 1854.

31 Boletim Musical. Jornal das Senhoras, Rio de Janeiro, ano 3, n. 21, p. 168, 21 maio 1854. Quinze dias depois, Joaninha dirá que "nosso dever é sempre registrarmos nas colunas deste jornal todas as belas composições que saem à luz do dia" (Boletim Musical. Jornal das Senhoras, Rio de Janeiro, ano 3, n. 23, p. 183, 4 jun. 1854).

32 Ver: MUZART, 2003, p. 227. A autora destaca o que considera "uma ação civilizadora" de Joana Paula Manso, "pois seu periódico trazia não somente moda e receitas de cozinha, mas também ideias e sugestões, pensamentos e críticas” (MUZART, 2003, p. 228). Ver também RODRIGUES, 2017, e BARBOSA, 2016. Este último trabalho é uma importante contribuição para a compreensão da presença da música no periódico.
} 
importância e utilidade, e que de suas aulas saíssem discípulos que o conceituassem e testemunhassem o incontestável merecimento de seus mestres. Mas não sabemos que mau fado o persegue: de sorte que nada apresentou ainda, nem mesmo matéria para um artigo ${ }^{33}$.

Apesar de Alina assinar apenas com um prenome - talvez um pseudônimo -, não se nota timidez na defesa veemente de um ponto de vista, em consonância com intelectuais homens, como Araújo Porto-Alegre ou Joaquim Manuel de Macedo, que atuavam na esfera pública e se batiam pela responsabilização do poder público e das elites com relação ao Conservatório. É a imprensa feminina atuando como um poderoso veículo de formação de opinião e intervenção sobre a vida pública, de modo oposto ao estereótipo atribuído à mulher, de passividade e recolhimento à vida doméstica. Sobre a possibilidade de se tratar de um pseudônimo, vale observar que embora o uso dos prenomes sem os respectivos sobrenomes possa indicar um desejo de permanecer incógnitas, também se pode aventar aí um aspecto afirmativo da condição feminina: os sobrenomes pertencem aos pais ou aos maridos ao passo que é o prenome que efetivamente gera a identidade feminina. Essa perspectiva parece-me muito mais coerente com o teor dos textos da redatora em análise.

Na edição seguinte, Alina volta à carga e toma como pretexto a apresentação de uma banda de menores para lamentar não ser o Conservatório capaz de dar mostra do adiantamento de seus discípulos. E propositiva, conclui: "Talvez que esta impossibilidade seja devida ao sistema de ensino, e tanto disso estamos persuadidas que desde já propomos a quem competir a reforma desse sistema que tão mal tem provado neste útil estabelecimento de belas artes" ${ }^{\prime 34}$. Na época, Manuel de Araújo Porto-Alegre estava encarregado de dirigir e reformar a Academia de Belas Artes e, em 1855, para resolver a situação precária do Conservatório, vinculou-o à Academia e, em seguida, propôs a criação da Ópera Nacional. Note-se que o Conservatório já fora objeto de uma das primeiras edições da revista. Em artigo assinado apenas com "R.", alguém se queixava de que "apesar da sua reconhecida utilidade, não tem a proteção que merece", e cobrava o preenchimento das cadeiras docentes. ${ }^{35}$ É grande a sintonia desse outro texto com as ideias de Porto-Alegre e isto se nota pela inclusão da música entre as belas artes - título do artigo e base da fusão do Conservatório à Academia -, pela forma como o autor se refere ao fundador do Conservatório e à decadência da música no período regencial e até pela expressão que Porto-Alegre empregaria em um escrito de 1856, em que se referia ao Rio de Janeiro como "a cidade dos pianos"36.

Embora o Conservatório não estivesse voltado aos jovens das famílias abastadas, nas quais o Jornal das Senhoras devia ter maior acolhida, é possível que algumas leitoras tivessem filhos matriculados ali. Mas se não fosse o interesse de mães, certamente seria o de consumidoras de música que moveria redatoras e leitoras. 0 caráter militante dos textos

\footnotetext{
33 Boletim Musical. Jornal das Senhoras, Rio de Janeiro, ano 3, n. 13, p. 102, 26 mar. 1854.

34 Boletim Musical. Jornal das Senhoras, Rio de Janeiro, ano 3, n. 14, p. 112, 2 abr. 1854.

35 Belas Artes. O Jornal das Senhoras, Rio de Janeiro, ano 1, n. 3, p. 22, 18 jan. 1852.

${ }^{36}$ Em trabahhos anteriores, discuto as ideias e a atuação de Araújo Porto-Alegre (PEREIRA, 2016 e $2018 a$ ).
} 
amplificava aspirações coletivas e afetava o campo intelectual, provocando um clima favorável a ações concretas. Sem acesso à identidade de Alina, só resta especular, sem que se possa investigar a interface com outros intelectuais. Mas é evidente que essas redatoras eram também leitoras e estavam informadas dos debates públicos e suas ressonâncias na imprensa. Por outro lado, o tema estava no ar e, seguramente, nas rodas dos salões, entre as toilettes e as danças da moda, falava-se do meio musical. A discussão dá uma boa medida de como o sistema da moda estava inserido no cotidiano daquela sociedade e ao contrário de uma suposta frivolidade, casos assim testemunham como essas revistas podiam ser condições e mecanismos relevantes para a atuação pública das mulheres.

O protagonismo feminino d'O Jornal das Senhoras também aparece na divulgação de músicas compostas por mulheres, dando-lhes visibilidade e projeção na esfera pública. A menção às compositoras não é exclusiva nem predominante, e tampouco elas são vistas como excepcionalidade. Se no caso relatado dos concursos d'A Estação parecia haver a necessidade de um incentivo que trouxesse essas compositoras à mostra, cinquenta anos antes, as composições das mulheres são nomeadas ao lado das dos homens, indicando tratar-se de um fenômeno habitual e conhecido, ao contrário da memória construída pela historiografia da música no Brasil. 0 caráter efêmero dessa música, e o "pouco estudo que ela requer"37, como dizia Ritinha no trecho citado anteriormente, terá contribuído para sua invisibilização posterior. Mas isso se deve também aos valores da musicologia tradicional, que enfatiza as "grandes obras" e tende a ver essa música de salão como música menor. Os concertos públicos são superdimensionados em detrimento dos privados, nos quais as mulheres eram bem atuantes $^{38}$. A exclusão das compositoras do cânone musical, ancorada no pressuposto da domesticidade e da superficialidade de sua criação, diz mais sobre a memória construída e sobre a própria historiografia da música do que sobre o passado histórico-musical. Ao trazer à luz o papel e o lugar da mulher nas atividades musicais das sociedades ocidentais do século XIX, a musicologia feminista convida a repensar as hierarquias entre os espaços público e privado, antes vistos respectivamente como coletivo e individual. 0 âmbito doméstico seria subjetivo, não comunicacional e menos relevante. Ao contrário, ainda que o espaço privado não seja massivo como um teatro de concerto, não deixa de ser coletivo, e a presença da música em saraus e bailes nos salões oitocentistas pode ter tido mais peso para as identidades sociais que os espaços amplos de teatros e salas de concerto. Sem contar que a atuação de mulheres no ensino de música, ainda quando fosse privada, não era rara nem oculta ${ }^{39}$. E, claro, a publicação de partituras como suplementos de periódicos ou como edições autônomas é outra face visível de sua atuação na esfera pública.

\footnotetext{
37 Modas. Jornal das Senhoras, Rio de Janeiro, ano 3, n. 13, p. 97-98, 26 mar. 1854.

38 Para Pilar Ramos, musicóloga espanhola, "el estudio de la actividad musical de las mujeres ha llevado a reconsiderar la significación de los espacios públicos y privados. [...] Si la historiografía había valorado el concierto público de los virtuosos del XIX como el gran acontecimiento musical, investigaciones recientes han demostrado cómo compositores y aficionados valoraban extraordinariamente los conciertos privados, para los cuales se reservaban los repertorios y estrenos más exquisitos" (RAMOS, 2010, p. 18).

39 Uma consulta ao Almanack Laemmert revela que, entre 1852 e 1855, entre os professores que se anunciavam como de "piano e canto" no Rio de Janeiro cerca de $20 \%$ eram mulheres.
} 
Mas nem sempre a visibilidade era requerida pelas mulheres, caso das compositoras que oJornal das Senhoras publicou. Em junho de 1853, anunciava-se a partitura de um romance, Saudades da minha terra, "por uma Senhora Provinciana, dedicado às suas coprovincianas maranhenses", e dizia-se: "Sentimos em consideração ao respeito que devemos a esta senhora e à louvável modéstia de suas ordens, não poder declarar seu nome às nossas assinantes, para que nele reconhecessem elas mais uma virtuosa mãe, boa filha, esposa e amiga carinhosa"40. Nota-se a necessidade de afirmar um código de "normalidade" sobre essa senhora, que respondia ao chamado para se expressar em público, mas não arriscava se revelar. Cumpria-se o programa original de Joana Manso, em que a revista é assim descrita: "Confidente discreto das vossas produções literárias; elas serão publicadas debaixo do anônimo: porém, não temais confiar-mo-las, nem temais dar expansão ao vosso pensamento"41. Algumas leitoras reagiram logo ao convite e uma seção de "Correspondências" trazia "pensamentos sobre a amizade" de uma leitora, um poema de outra e uma crônica de uma tercei$\mathrm{ra}^{42}$. Por uma fatalidade, terminamos sabendo o nome da responsável pelos pensamentos. Emília Dulce Moncorvo de Figueiredo (1829-1852) morreria em março, pouco depois de dar à luz a filha de mesmo nome, que atuaria na Associação Promotora da Instrução de Meninas e seria conhecida como a escritora Carmen Dolores, seu pseudônimo mais difundido. Em maio de 1852, Joana Manso publica a valsa As lágrimas da amizade, "testemunho de veneração à memória" de "nossa sempre pranteada colaboradora e amiga sincera" 43 .

Além das partituras das que preferiam manter-se incógnitas, é possível acessar pelo "Boletim Musical" os nomes de outras compositoras. Entre as recomendações de Joaninha, acham-se Os poetas brasileiros e A flor da esperança, valsas da mineira Francisca Pinheiro de Aguiar, e Russiana, quadrilha da Madame de Mattos. Sobre a primeira, diz que "esta senhora, conhecida pelo seu talento musical, há por mais de uma vez demonstrado todo o gosto da arte nas suas diferentes composições" ${ }^{44}$. Infelizmente, a única partitura sua conservada na Biblioteca Nacional é a da A flor da esperança, que Joaninha diz ter ouvido "outra noite, executada por uma nossa interessante amiga do Catete", e da qual dá suas impressões:

Há uma dolorosa sensação para a alma, um saudoso e terno encanto para o coração ao ouvir-se tocar tão lindíssima valsa.

\footnotetext{
40 Jornal das Senhoras, Rio de Janeiro, ano 2, n. 26, p. 202, 26 jun. 1853. Infelizmente a partitura não se encontra na Hemeroteca Digital da Biblioteca Nacional.

${ }^{41}$ NORONHA, Joana Paula Manso de. Às nossas assinantes. O Jornal das Senhoras, Rio de Janeiro, ano 1, n. 1, p. 1, 1으 jan. 1852.

42 Correspondências. O Jornal das Senhoras, Rio de Janeiro, ano 1, n. 6, p. 44, 8 fev. 1852.

43 Jornal das Senhoras, Rio de Janeiro, ano 1, n. 22, p. 175, 30 maio 1852. A partitura está disponível na Hemeroteca Digital da Biblioteca Nacional.

${ }^{44}$ Boletim Musical. Jornal das Senhoras, Rio de Janeiro, ano 3, n. 21, p. 168, 21 maio 1854.
} 
Foi um verdadeiro sonho de imaginação conceber-se um pensamento assim tão repassado de magia, e decifrá-lo na música, na mimosa Flor da Esperança, que melancolicamente nos vai extasiando ${ }^{45}$.

0 trecho, todo repassado de impressões dolorosas, saudosas, ternas, oníricas, mágicas e melancólicas, parece confirmar os supostos atributos de uma sensibilidade feminina que seriam associados a toda composição saída da pena de uma mulher, e contrapostos à elaboração formal, que seria exclusiva dos homens, dotados, estes sim, de "gênio". Ao contrário, a maior parte da produção musical da época, fosse de homem ou de mulher, estava destinada aos salões e correspondia a essa mesma sensibilidade romântica. Além disso, nem tudo é melancolia nas composições femininas, e Joaninha diz às leitoras que a quadrilha Russiana, de Madame de Mattos, "foi tocada em alguns bailes, e ouvida com geral agrado, pois que ela é por demais encantadora para não fascinar com a sua animada música"46. Ao anunciar a casa onde se podia comprá-la, lembra que ali também está à venda a valsa de Francisca Pinheiro de Aguiar, $A$ flor da esperança, "cuja primeira edição tinha sido esgotada, e que se acha agora reimpressa". E assim ficamos sabendo que as composições de mulheres nem sempre eram destinadas exclusivamente ao âmbito doméstico, vinham a público, faziam enorme sucesso e vendiam muito.

\section{Entre o lazer e o trabalho: amadoras e compositoras}

Vimos que o concurso realizado pel'A Estação em 1902 convocava "compositoras e amadoras" e agora é hora de abordar essa diferença. Dois contos de Machado de Assis saídos no Jornal das Famílias ajudam a entender o que leva as compositoras ao anonimato ou à visibilidade. Nas duas ficções, as protagonistas são jovens mulheres cujas decisões sobre o casamento orientam a narrativa, e cujas relações com a música as definem. Malvina, moça pobre, é $A$ pianista, título que traduz a identidade da personagem pelo instrumento musical. Luíza, moça rica, é Uma loureira, isto é, uma mulher sedutora e provocante, mas dissimulada, que sabia valer-se dos atributos femininos sem se identificar com eles: "Vestia bem, mas aborrecia o luxo. Tocava piano, mas aborrecia a música" ${ }^{47}$. A mãe de Luíza desejava que ela "continuasse a tradição que recebera", "uma linha não interrompida de boas donas de casa". Mas a moça tinha ideias próprias: frustra essas expectativas e também as de dois pretendentes que a disputam ao enganar a todos, oscilando entre eles, para terminar fugindo com o primo do qual Machado diz que "dificilmente se acharia outro mais papalvo que ele"48. Senhora do seu destino, prefere

\footnotetext{
45 Boletim Musical. Jornal das Senhoras, Rio de Janeiro, ano 3, n. 23, p. 183, 4 jun. 1854. A composição de Francisca Pinheiro de Aguiar foi publicada como suplemento musical de $A$ rosa brasileira, conforme anúncio publicado em A rosa brasileira, Rio de Janeiro, ano 4, n. 6, p. 8, 3 abr. 1853. 0 exemplar da partitura pertencente à Biblioteca Nacional parece tratar-se de um manuscrito e não do referido suplemento.

${ }^{46}$ Boletim Musical. Jornal das Senhoras, Rio de Janeiro, ano 3, n. 30, p. 240, 23 jul. 1854.

47 Uma loureira, Jornal das Famílias. Rio de Janeiro, t. X, n. 5, p. 140-150, maio 1872. A citação corresponde à p. 142

48 Uma loureira, Jornal das Famílias. Rio de Janeiro, t. X, n. 6, p. 161-170, jun. 1872. A citação corresponde à p. 163.
} 
o pateta, a quem poderia dominar facilmente. Ao contrário dessa loureira, que tinha o piano apenas como instrumento de representação social, a pianista "ensinava piano. Era esse o único recurso que tinha para sustentar-se e à sua mãe, pobre velha a quem os anos e a fadiga de uma vida trabalhosa não permitiam já tomar parte nos labores de sua filha"49.

$\mathrm{O}$ contraste entre as duas personagens machadianas sugere haver mulheres que se divertem e mulheres que se sustentam com a música, o que poderia determinar o comportamento de uma compositora perante a esfera pública. Se ela se oculta ou se mostra no espelho da imprensa não é por capricho pessoal, mas por um corte de classe ou por uma vicissitude. Mesmo mulheres de alguma condição podiam se ver na contingência de se lançar ao mercado da música para sobreviver. É o caso, conhecido, de Chiquinha Gonzaga. É o caso, esquecido, da Condessa Rafaela de Rozwadowska (c. 1816-1906), que teve duas composições publicadas pela Revista Popular, a valsa $O$ feliz regresso e a schottisch Mofina. Ao contrário das demais partituras publicadas pela revista disponíveis na Hemeroteca Digital da Biblioteca Nacional, as da condessa estão na Divisão de Música e Arquivo Sonoro, e digitalizadas, mas sem indicação do ano de publicação. Além delas, a Biblioteca Nacional conserva Paysandu, hino de guerra publicado durante a Guerra do Paraguai. Não era hábito da revista anunciar ou comentar os suplementos, o que dificulta identificar as datas das partituras avulsas, mas, consultando-se a coleção na Hemeroteca, notam-se duas partituras por ano, faltando as de 1862, o que me permite supor como sendo a datação.

A única referência à condessa na revista data de março de 1861, não como compositora, mas como "talvez a primeira pianista existente entre nós", que, segundo a "Crônica da Quinzena", havia convocado "as famílias das suas numerosas discípulas para um grande concerto vocal e instrumental" no teatro Santa Tereza, em Niterói, acompanhada por outros instrumentistas e artistas da Ópera Nacional ${ }^{50}$. A informação reforça o que se lê nas partituras: a valsa é "dedicada às suas discípulas as Exmas. Sras. DD. T.J. e P.R. da Costa Miranda”, e a schottisch é "dedicada à sua discípula a Sra. D. Idalina de Andrade". Uma consulta aos jornais da Corte traz mais dados sobre a condessa. Em concertos realizados anteriormente, ela tocara composições suas, o que mais uma vez não suscita espanto dos cronistas. Uma mulher compondo e executando suas peças em público não era motivo de reparo. Além disso, a seção de anúncios do Diário do Rio de Janeiro de 5 de dezembro de 1857 traz um em que se lê: "A condessa de Rozwadowska leciona piano, canto e composição. Rápido e sólido adiantamento das discípulas garantido. Preços cômodos conforme a distância" ${ }^{1}$. E ficamos sabendo que, além de mulheres compositoras, já havia a mulher compositora que ensinava composição a outras mulheres. Aproveitando o espaço, eram anunciadas também uma Grande valsa de bravura e uma polca de ocasião, Treze de junho, alusiva à passagem de um cometa.

Uma condessa de origem italiana, casada com um polonês, que dá aulas de piano, canto e composição, apresenta-se em concertos, edita suas composições e se oferece no mercado de música a "preços cômodos", parece pôr em questão a dicotomia que opõe entretenimento

\footnotetext{
49 A pianista. Jornal das Famílias, Rio de Janeiro, t. IV, p. 257-269, set. 1866 e p. 289-300, out. 1866. A citação corresponde à p. 257.

50 Crônica da Quinzena. Revista Popular, Riåo de Janeiro, ano 3, n. 9, p. 249-256, jan./mar. 1861. A citação corresponde à p. 256.

51 Diário do Rio de Janeiro, Rio de Janeiro, ano 37, n. 330, p. 3, 5 dez. 1857.
} 
e trabalho. Por ser mulher e estrangeira, os dados disponíveis na bibliografia são escassos e desencontrados, o que requereu uma pesquisa não relatada aqui em profundidade e que confirma a discussão sobre compositoras que optam pelo anonimato ou pela exposição pública ${ }^{52} .0$ caso é paradigmático. Rafaela de Rozwadowska embarcou para o Brasil em dezembro de 1851 acompanhada do filho e do marido, um polonês formado em engenharia militar em Viena, que deu baixa do exército imperial austríaco após participar da repressão à Revolução de 1848, partiu para a Turquia, pretendendo engajar-se no exército turco, para então atender a um chamado do governo brasileiro que atraía oficiais e soldados europeus. Um perfil de aventureiro, digno de folhetim. Após missões na campanha do Uruguai e no Amazonas, entrou em conflito com o vice-presidente da província, acusando-o de corrupção, e com o comando do exército, vindo a ser desligado do mesmo, dando início então a uma campanha para receber os soldos que julgava ter direito (ROZWADOWSKI, 1857). Certamente, não foi por diletantismo que a senhora condessa lançou-se no mercado de música. E ela sabia se expor como poucas. A ocasião provável da publicação das partituras na Revista Popular, em 1862, correspondia à visibilidade então alcançada com a encenação, pela Ópera Nacional, de uma ópera de sua autoria sobre libreto, traduzido para o português por Manuel Antônio de Almeida, dedicada à imperatriz e que estreou em espetáculo de gala pelo aniversário do imperador, em 2 de dezembro de 1861. Mas a recepção foi fria. Uma nova récita foi programada para o fim do mês, quando então a condessa faz publicar, abaixo do anúncio, a seguinte nota, muito esclarecedora:

Não constando à abaixo assinada que a empresa tivesse procedido a um só ensaio dessa ópera com o pessoal da orquestra e cena completo, declara que está alheia à representação que a empresa sem conhecimento nenhum dela hoje anunciou. Rio, 19 de dezembro de 1861, Condessa de Rozwadowska ${ }^{53}$

A queixa parece ter surtido efeito e três dias depois repetia-se o anúncio da segunda récita da ópera, "novamente ensaiada com todo o pessoal de canto e orquestra"54. Em lugar de fragilidade, protagonismo. Em lugar de recolhimento, visibilidade. Em lugar de silêncio, música. Mas apenas três partituras conservadas nos arquivos...

\section{A música seguindo a moda ${ }^{55}$}

Considerando-se o que tem sido apontado neste trabalho acerca dos diferentes modos como as revistas femininas captaram a música como parte integrante do sistema da moda,

\footnotetext{
52 Em outro trabalho, abordo com mais atenção o "caso Rozwadowska” (PEREIRA, 2019).

53 Diário do Rio de Janeiro, Rio de Janeiro, ano 41, n. 347, p. 4, 20 dez. 1861.

${ }^{54}$ Diário do Rio de Janeiro, Rio de Janeiro, ano 41, n. 350, p. 4, 23 dez. 1861.

${ }^{5} \mathrm{Na}$ apresentação oral de uma versão deste trabalho, no Colóquio Imprensa, Moda e Mulher: trânsitos, circulação e trocas, realizado em agosto de 2018 na Fundação Casa de Rui Barbosa, pelo grupo de pesquisa Imprensa e Circulação de Ideias: o papel dos periódicos no século XIX e XX, a pesquisadora Maria Cristina Volpi, a quem agradeço imensamente, fez um sugestivo questionamento sobre a possibilidade de se identificar de que modo a música pode ter acompanhado as transformações da moda durante o período abarcado pela pesquisa. A última seção deste texto é uma tentativa de desenvolver ou encaminhar a questão.
} 
não é descabido supor uma sintonia entre as alterações estilísticas sofridas pela música nos cinquenta anos estudados e as modificações nos trajes e adereços usados pelas mulheres. Não se trata, no caso, de nenhum espelhamento, mas de uma conformidade em termos de sensibilidades e gostos, fruto da circulação de tendências. Uma questão de moda, enfim.

Claro que considerar aspectos estilísticos da década de 1850 implica tomar o romantismo como padrão de sensibilidade, cujas características inclusive são, não raramente, associadas ao feminino exatamente pela ênfase no sentimento, na comunicação das emoções e na intenção de se valer das expressões artísticas para comover os fruidores. Nesse sentido, remeto aos comentários de Joaninha, nas páginas do Jornal das Senhoras, ao divulgar a valsa $A$ flor da esperança, de Francisca Pinheiro de Aguiar, que a caracteriza como "um sonho de imaginação", "repassado de magia", "que melancolicamente nos vai extasiando"56. Os próprios títulos de algumas das composições parecem reforçar esse tipo de impressão. Podemos lembrar a mencionada valsa As lágrimas de amizade, de Emília Dulce Moncorvo de Figueiredo, publicada em 1852, ou a schottisch Saudosa, da premiada Rita Peixoto Guimarães, publicada pel'A Estação, em 1902. Mas como já sugeri antes, essas características "femininas" não seriam exclusivas de composições saídas de pena - nos dois sentidos! - de mulher. Conforme as tendências românticas, também os homens compunham trechos repassados de dores e amores e apelavam para títulos evocativos e nostálgicos. Um bom exemplo pode ser encontrado no próprio O Jornal das Senhoras: a valsa As lágrimas da saudade, de Joseph Fachinetti, publicada em suplemento na edição de número 35, de 29 de agosto de 1852. Por outro lado, e ampliando-se o escopo da pesquisa para além dos suplementos dos periódicos, nem sempre as compositoras nos brindam com títulos assim melancólicos. E para isso servem as habaneras: Sempre travessa, de Amália Pimentel, por exemplo. Já no plano da sensualidade, pode-se recorrer à polca Atraente ou ao tango Sedutor, que para isso temos Chiquinha Gonzaga. E que tal essa outra polca, Sultana, ou ainda a Mulher-homem, ambas da lavra de Chiquinha? Avançando para o fim do século, portanto, já estaríamos distantes daquela sensibilidade romântica dos anos 1850. A sensualidade, o humor, a picardia expressariam novas sensibilidades, talvez indicando também novos padrões de comportamento que algumas mulheres podiam ostentar socialmente.

Mas, para me ater às revistas, opto por uma breve comparação entre $A$ flor da esperança, de Francisca Pinheiro de Aguiar, tão decantada nas páginas de O Jornal das Senhoras, e a schottisch Marthe, da premiada Leontina Gentil Torres. No primeiro caso, em parte reiterando as impressões melancólicas captadas pela redatora da crônica musical, poderíamos até falar em certa timidez da compositora, pelo modo como ela explora - ou pouco explora - o teclado do piano. Os acordes do acompanhamento no segundo e terceiro tempos da valsa são sempre apresentados em posição fechada e na mesma região, isto é, sem que se aproveite uma extensão maior, "espalhando-se" pelo teclado. É uma impressão contida que daí nasce, condizente, é claro, com a intenção melancólica geral da peça, já sugerida desde o título. Por outro lado, isso é reforçado pela mão direita, em que se recorrem a ornamentos - apoggiaturas oitavando acima os sons da melodia e trinados - que contribuem para

56 Ver citação correspondente à nota 36 , supra. 
dar certa "delicadeza" à execução. Diria metaforicamente que um desenho curvilíneo parece orientar a construção da melodia.

Já Leontina, compondo quase cinquenta anos depois, no princípio do século XX, apresenta uma partitura vigorosa, em "linhas retas", e em tudo contraposta ao que rotulei como "timidez" e "delicadeza”. Logo na primeira seção, que se repetirá algumas vezes ao longo da partitura, como era comum nas danças que seguiam a chamada forma rondó, a melodia aparece oitavada nas duas mãos, o que resulta inevitavelmente em grande sonoridade na execução - e essa provavelmente foi a intenção da compositora. Além disso, embora os acordes do acompanhamento também se repitam em posição fechada - como na valsa de Francisca -, o movimento do baixo dá uma sensação de mais deslocamento e saltos das mãos, dominando uma extensão maior do teclado. Em suma, se a valsa de Francisca era intimista, a schottisch de Leontina indica mais exterioridade pelo caráter vibrante e pela sonoridade mais intensa. Seria forçado dizer que ela soa mais "masculina"? Ou, para usar uma palavra mais corrente nos dias atuais, diríamos que ela soa mais "empoderada", como quem não pede licença para ocupar os teclados e os salões?

Se essas impressões gerais forem válidas, será possível associar a maior sonoridade e o maior domínio sobre a extensão do teclado - que aqui represento como atributos "masculinos" - a certas tendências da moda, vestuário e adereços com que as mulheres se apropriam de elementos dos trajes masculinos, como as gravatas, por exemplo, instabilizando relações tradicionalmente estabelecidas. Já nas páginas do próprio O Jornal das Senhoras, o "colete da emancipação", isto é, a apropriação de um elemento do vestuário masculino pelas senhoras, era apontado como um dado do projeto de emancipação feminina que a revista propunha como parte de seu programa. Essas apropriações visavam exatamente a afirmar novos papeis à mulher na esfera pública.

Essas breves considerações musicológicas podem certamente parecer forçadas, mas constituem alguns dos pontos sob investigação da musicologia feminista, que tenta definir traços distintivos de uma possível representação masculina ou feminina nas composições musicais. Sem a pretensão de chegar a definições estritamente codificadas, quis compartilhar algumas reflexões resultantes do contato com as fontes, constituindo antes uma provocação à investigação do que alguma certeza conclusiva. 


\section{Referências}

BARBOSA, Everton Vieira. Páginas de sociabilidade feminina: sensibilidade musical no Rio de Janeiro oitocentista. Dissertação (Mestrado) - Faculdade de Ciências e Letras de Assis, Universidade Estadual Paulista, Assis, 2016.

BUITONI, Dulcília Schroeder. Imprensa feminina. São Paulo: Ática, 1986.

CORREIO DAS MODAS. Rio de Janeiro, 1839-1840.

DIÁRIO DO RIO DE JANEIRO. Rio de Janeiro, 1821-1858.

DUARTE, Constância Lima. Imprensa feminina e feminista no Brasil: século XIX dicionário ilustrado. Belo Horizonte: Autêntica, 2016.

O ESPELHO. Rio de Janeiro: 1859-1860.

A ESTAÇÃO. Rio de Janeiro: 1879-1904.

JORNAL DAS FAMÍLIAS. Rio de Janeiro: 1863-1878.

O JORNAL DAS SENHORAS. Rio de Janeiro: 1852-1855.

LUCA, Tania Regina de. Mulheres em revista. In: PINSKY, Carla Bassanezi; PEDRO, Joana Maria (orgs.). Nova história das mulheres no Brasil. São Paulo: Contexto, 2018, p. 447-468.

MUZART, Zahidé Lupinacci. Uma espiada na imprensa das mulheres no século XIX. Estudos Feministas, v. 11, n. 1, p. 225-233, jan./jun. 2003. Disponível em: https://periodicos.ufsc. br/index.php/ref/article/view/S0104-026X2003000100013. Acesso em: 9 jun. 2019.

NOGUEIRA, Isabel Porto; FONSECA, Susan Campos (orgs.). Estudos de gênero, corpo e música: abordagens metodológicas. Goiânia, Porto Alegre: ANPPOM, 2013. Disponível em: https:// www.anppom.com.br/ebooks/index.php/pmb/catalog/book/3. Acesso em: 9 jun. 2019.

PEREIRA, Avelino Romero. Uma "empresa útil, elevada e patriótica": os intelectuais e o movimento pela Ópera Nacional no Rio de Janeiro oitocentista. In: SARMIENTO, Érica et al. (orgs.). Movimentos, trânsitos \& memórias: temas e abordagens. Niterói: Universo, 2016, p. 86-97. Disponível em: https://coloquiomovimentos.wixsite.com/2016/e-book. Acesso em: 9 jun. 2019.

PEREIRA, Avelino Romero. As ideias sobre a música no mecenato imperial. In: BAREL, Ana Beatriz; COSTA, Wilma (orgs.). Cultura e poder entre o Império e a República: estudos sobre os imaginários brasileiros (1822-1930). São Paulo: Alameda, 2018a, p. 85-112. 
PEREIRA, Avelino Romero. Cultura musical e palavra impressa no Brasil oitocentista. In: BESSONE, Tânia et al. (orgs.). Imprensa, livros e política no Oitocentos. São Paulo: Alameda, 2018b, p. 15-49.

PEREIRA, Avelino Romero. Mulheres compositoras no Rio de Janeiro oitocentista: a condessa Rozwadowska. In: CARVALHO, Marieta de et al. (orgs.). Movimentos, trânsitos \& memórias: novas perspectivas. Vol. 1. Niterói: Universo, 2019, p. 286-301. Disponível em: https://coloquiomovimentos.wixsite.com/2019/e-book. Acesso em: 26 maio 2020.

RAMOS, Pilar. Luces y sombras en los estudios sobre las mujeres y la música. Revista Musical Chilena, v. 64, n. 213, p. 7-25, jan./jun. 2010. Disponível em: https://revistamusicalchilena. uchile.cl/index.php/RMCH/issue/view/225. Acesso em: 9 jun. 2019.

REICH, Nancy. Women as musicians: a question of class. In: SOLIE, Ruth. Musicology and difference: gender and sexuality in music scholarship. Berkeley: University of California Press, 1993, p. 125-146.

REVISTA POPULAR. Rio de Janeiro, 1859-1862.

RODRIGUES, Dayanny. Escritos de e para mulheres no século XIX: o conceito de emancipação e a representação feminina no Jornal das Senhoras. Revista Outras Fronteiras, v. 4, n. 1, p. 54-76, jan./jul. 2017. Disponível em: http://ppghis.com/outrasfronteiras/index.php/ outrasfronteiras/article/view/256. Acesso em: 9 jun. 2019.

A ROSA BRASILEIRA. Rio de Janeiro: 1853.

ROZWADOWSKI, Florian (Conde de). O governo e a colonização: ou considerações sobre o Brasil e o engajamento de estrangeiros. Rio de Janeiro: s. ed., 1857.

TODD, R. Larry (org.). Nineteenth-century piano music. Nova York: Schirmer, 1994.

ZAMITH, Rosa Maria. A quadrilha: da partitura aos espaços festivos: música, dança e sociabilidade no Rio de Janeiro oitocentista. Rio de Janeiro: E-papers, 2011. 